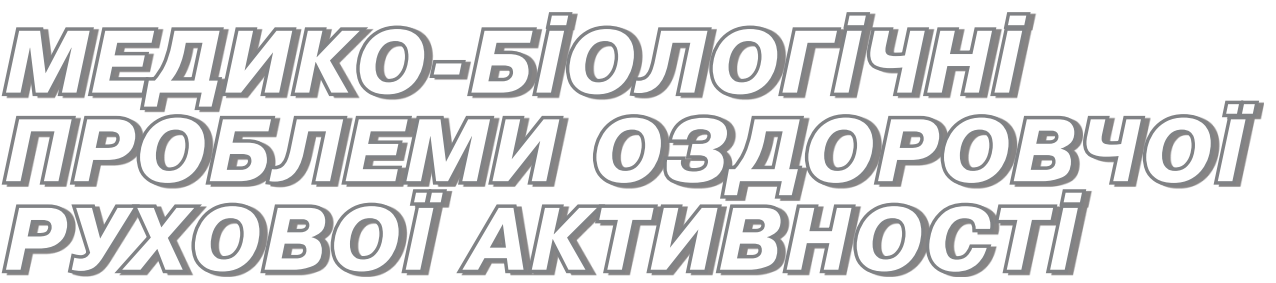

DOI: https://doi.org/10.32652/spmed.2019.1.81-85

\title{
Базові положення побудови профілактично-оздоровчих програм для працівників атомних електростанцій
}

\author{
УДК 621.311.25 - 057.2:615.825+796.035 \\ М. В. Дутчак, О. В. Андрєєва, О. Б. Лазарєва,
О. Л. Благій, і. В. Хрипко
}

Національний університет фізичного виховання і спорту України, Київ, Україна

\begin{abstract}
Резюме. Мета. Дослідити особливості професійної діяльності, рівня захворюваності, мотивації працівників атомної електростанції як базових складових розробки профілактичнооздоровчих, рекреаційних та реабілітаційних програм. Методи. Аналіз і систематизація науково-методичної літератури та документальних матеріалів; компаративний метод; абстрагування, логіко-теоретичний аналіз, системний підхід; аналіз і синтез, спостереження, опитування, експертна оцінка, анкетування, моделювання, методи математичної статистики. Висновки. На основі принципів системного підходу і всебічного ретельного вивчення професійної діяльності фахівців атомної галузі, програмно-нормативних джерел, професіографічних досліджень, даних анкетування фахівців, освітньо-кваліфікаційних характеристик, довідників професій, наявних захворювань, скарг працівників було складено експериментальні програми фізичної реабілітації, профілактично-оздоровчих та рекреаційних занять. Перспективи подальших досліджень полягають в оцінці ефективності розроблених профілактично-оздоровчих, рекреаційних та реабілітаційних заходів для працівників атомних електростанцій.
\end{abstract}

Ключові слова: профілактично-оздоровчі програми, рекреаційні програми, реабілітаційні програми, працівники, атомні електростанції.

\section{Базовые положения построения профилактически-оздоровительных программ для работников атомных электростанций}

М. В. Дутчак, Е. В. Андреева, Е. Б. Лазарева, А. Л. Благий, И. В. Хрипко.

Национальный университет физического воспитания и спорта Украины, Киев, Украина

\begin{abstract}
Резюме. Цель. Выявить особенности профессиональной деятельности, уровня заболеваемости, мотивации работников атомной электростанции как базовых составляющих разработки профилактически-оздоровительных, рекреационных и реабилитационных программ. Методы. Анализ и систематизация научно-методической литературы и документальных материалов; компаративный метод, абстрагирование, логико-теоретический анализ, системный подход; анализ и синтез, наблюдение, опрос, экспертная оценка, анкетирование, моделирование, методы математической статистики. Выводы. На основе принципов системного подхода и всестороннего изучения профессиональной деятельности специалистов атомной отрасли, программно-нормативных источников, профессиографических исследований, данных анкетирования специалистов, образовательно-квалификационных характеристик, справочников профессий, имеющихся заболеваний, жалоб работников были составлены экспериментальные программы физической реабилитации, профилактически-оздоровительных и рекреационных занятий. Перспективы дальнейших исследований заключаются в оценке эффективности разработанных профилактически-оздоровительных, рекреационных и реабилитационных мероприятий для работников атомных электростанций.
\end{abstract}


Ключевые слова: профилактически-оздоровительные программы, рекреационные программы, реабилитационные программы, работники, атомные электростанции

\title{
Basic provisions for designing preventive and health related programs for employees of nuclear power plants
}

M. v. Dutchak, O. V. Andreieva, O. B. Lazarieva, O. L. Blagii, i. v. Khrypko

National University of Physical Education and Sport of Ukraine, Kyiv, Ukraine

\begin{abstract}
Objective. To study the peculiarities of professional activity, morbidity level, motivation of nuclear power plant employees as the basic constituents of development of preventive and health related, recreational and rehabilitation programs. Methods. Analysis and systematization of scientific and methodological literature and documentary materials; comparative method; abstraction, logical-theoretical analysis, systematic approach; analysis and synthesis, observations, surveys, expert assessment, questioning, modeling, methods of mathematical statistics. Conclusions. On the basis of the principles of a systematic approach and thorough study of the professional activity of the specialists of the nuclear industry, program-normative sources, job analyses, data of questionnaires of specialists, educational and qualification characteristics, references to professions, existing diseases, complaints of employees, experimental programs of physical rehabilitation, health related and preventive sessions were created. The prospects for further research are to evaluate the effectiveness of the developed preventive and health related, recreational and rehabilitation measures for the employees of nuclear power plants.
\end{abstract}

Keywords: preventive and health related programs, recreational programs, rehabilitation programs, employees, nuclear power plants.

Постановка проблеми. Аналіз останніх досліджень та публікацій. Успішне фрункціонування такого стратегічно важливого комплексу, як атомна енергетика, багато в чому визначається людським чинником. Високі вимоги, що висуваються до оперативного персоналу атомних електростанцій, висвітлюють ряд основних протиріч між стрімким розвитком галузі й потребою у висококваліфікованих фрахівцях, здатних до тривалого професійного довголіття, та недостатньою розробленістю змісту наявних програм 3 фрізичної реабілітації та рекреації в концептуальному розумінні; між високими вимогами, що висуваються до фрізичної підготовленості сучасних фахівців галузі атомної енергетики, та наявним рівнем показників фрізичного та психоемоційного станів працівників [10].

На сьогодні багато дослідників наголошують на актуальності визначення та обгрунтування змісту профілактично-оздоровчих програм 3 урахуванням вимог конкретної професії та пошуку нових технологій її втілення [1, 3, 5, 11]. Ще одним аспектом, що викликає необхідність розробки профрілактично-оздоровчих заходів, $\epsilon$ захворюваність працівників АЕС. Під час аналізу захворюваності особливу увагу слід приділяти окремим класам хвороб, що характерні для населення України в цілому, зокрема для Рівненської області, оскільки згідно з даними, поданими начальником відділу охорони здоров'я служби охорони праці РАЕС Марією Смічик, захворюваність персоналу Рівненської атомної станції цілком корелюється із статистичними даними Рівненського обласного інформаційно-аналітичного центру медичної статистики. Зараз жодного випадку професійного захворювання на PAEC не зафіксовано. Аналіз захворюваності працівників PAEC за останні роки свідчить, що показники захворювань на PAEC $€$ нижчими, ніж середні в області та Україні. Захворюваність мешканців міста Вараш $€$ нижчою, ніж міст Рівне та Дубно.

Водночас, за даними начальника відділу охорони здоров'я служби охорони праці РАEC, найчастіше працівники станції звертаються із скаргами на здоров'я в осінньо-зимовий період з приводу респіраторно-вірусних захворювань. У структурі захворювань переважають хвороби органів дихання, кістково-м'язової системи та сполучної тканини (вертеброгенні дорсалгії, вертебро-базилярна недостатність, остеохондроз тощо), захворювання ока та його придаткового апарату, ендокринної системи, хронічні перенапруження. Чисельність виробничого персоналу (ВП) РАЕС становить 7875 осіб, серед них 4629 - це промислово-виробничий персонал зі шкідливими умовами праці. 3 огляду на те, що більшість працівників РАЕС належить до представників другого періоду зрілого віку (особи старші 36 років), мають стресовий характер роботи та більшість шкідливі умови праці, недостатню рухову активність, це зумовлює необхідність використання засобів фрізичної реабілітації, оздоровчого фрітнесу, фрізичної рекреації, що сприятимуть відновленню фрізичної та розумової 
працездатності, покращенню показників фрізичного стану, рівня фрізичного здоров'я, відновленню після хвороб та попередженню професійних захворювань персоналу атомної електростанції.

Ситуація, що склалася, зумовлює актуальність наукового обгрунтування вдосконалення змісту, розробки та впровадження чіткої системи оздоровчих, професійно-прикладних фрізкультурних заходів, спрямованих на збереження та підвищення здатності людини до трудової діяльності на виробництві $[2,4,7]$.

Дослідження виконано відповідно до Плану НДР НУФВСУ на 2016-2020 рр. згідно з темою кафедри здоров'я, фрітнесу та рекреації «Теоретико-методологічні засади оздоровчо-рекреаційної рухової активності різних груп населення» (номер держреєстрації 0116U001630).

Мета дослідження - дослідити особливості профресійної діяльності, рівня захворюваності, мотивації працівників атомної електростанції як базових складових розробки профілактично-оздоровчих, рекреаційних та реабілітаційних програм.

Методи дослідження: аналіз і систематизація науково-методичної літературитадокументальних матеріалів; компаративний метод; абстрагування, логіко-теоретичнийаналіз, системнийпідхід; аналіз і синтез, спостереження, опитування, експертна оцінка, анкетування, моделювання, методи математичної статистики.

Результати дослідження. Для детального вивчення специфіки професійної діяльності, складу профресійно важливих фрізичних і психофрізіологічних якостей та властивостей було проведено аналіз фрахової літератури, документальних та статистичних матеріалів із зазначеної проблеми. Встановлено, що ВП РАЕС включає такі групи фрахівців:

- за типом персоналу: промислово-виробничий, непромисловий;

- за категорією - керівник, профресіонал, фрахівець, службовець, робітник;

- за групою персоналу: експлуатаційний, оперативний, ремонтний.

До промислово-виробничого персоналу належать 6552 працівників, серед яких 1719 жінок, 4833 чоловіків. 3 них 4629 зі шкідливими умовами праці, 1923 - з нормальними умовами праці. За категоріями працівники розподілені як показано у таблиці 1.

За результатами дослідження визначено, що професійна діяльність працівників атомної станції залежить від багатьох чинників, зокрема характеру професійної діяльності, санітарно-гігієнічних умов виробництва тощо.
Спортивна медицина і фізична реабілітація, №1, 2019

ТАБЛИЦЯ 1 - Характеристика промислово-виробничого персоналу ВП РАЕС

\begin{tabular}{|l|c|c|c|c|c|}
\hline \multirow{2}{*}{\multicolumn{1}{|c|}{ Персонал }} & \multirow{2}{*}{$\begin{array}{c}\text { Кількість } \\
\text { загальна }\end{array}$} & \multicolumn{2}{|c|}{ Стать } & \multicolumn{2}{c|}{ Умови праці } \\
\cline { 3 - 6 } & & жінки & $\begin{array}{c}\text { чо- } \\
\text { ловіки }\end{array}$ & $\begin{array}{c}\text { нор- } \\
\text { мальні }\end{array}$ & $\begin{array}{c}\text { шкід- } \\
\text { ливі }\end{array}$ \\
\hline Керівник & 974 & 83 & 891 & 215 & 759 \\
Професіонал & 1396 & 512 & 883 & 770 & 625 \\
Робітник & 3941 & 921 & 3020 & 722 & 3219 \\
Службовець & 39 & 39 & 0 & 39 & 0 \\
Фахівець & 203 & 164 & 39 & 177 & 26 \\
Загальна кількість & 6552 & 1719 & 4833 & 1923 & 4629 \\
\hline
\end{tabular}

Умови праці фахівців експлуатаційної групи вирізняються такими особливостями: праця характеризується чергуванням проміжків часу зі значним фрізичним навантаженням 3 малим обсягом рухової активності, незначним фрізичним навантаженням; робота може відбуватися як на вулиці, так і в приміщенні; умови праці потребують від фахівців високого рівня розвитку загальної і силової витривалості, здатності витримувати багатогодинне фрізичне і розумове навантаження, підтримувати високий рівень працездатності впродовж робочої зміни; робота може відбуватися у закритих адміністративних і виробничих приміщеннях, де спостерігаються монотонний шум, шкідливе випромінювання від комп'ютерної техніки, підвищена сухість повітря при роботі кондиціонерів, недостатня провітрюваність приміщення; режим праці цілодобовий, робоча зміна може бути вдень і вночі, на ліквідацію надзвичайних випадків персонал можуть викликати на роботу додатково; праця часто відбувається в умовах нервово-емоційного напруження, стресу; під час виконання виробничих завдань відбувається велике напруження зорового аналізатора, центральної нервової системи; робота відбувається при несприятливих і дискомфортних умовах, таких, як тривалий малоінтенсивний шум, вібрація, забруднене, механічними і хімічними речовинами повітря, загазованість, запиленість, високий рівень вологості, негативний вплив кліматичних умов.

Аналіз результатів дослідження свідчить, що у фрахівців цієї профеесійної групи спостерігається середній рівень гострої захворюваності. Кількість календарних днів непрацездатності на 100 працюючих за всіма класами хвороб становить 775,30 дня (у тому числі через гострі респіраторні інфекції верхніх та нижніх дихальних шляхів50,82 дня). Показники частоти захворюваності свідчать, що більше половини працюючих хворіють 1-2 рази на рік; третина - 3-4 рази на рік. Тільки у незначної кількості працівників (переважно оперативний персонал) відмічається відсутність захворювань протягом поточного року. 
Структуру поширеності хвороб в останні роки формували переважно хвороби органів дихання $(58,42 \%)$, органів травлення $(14,1 \%)$, кістковом'язової системи та сполучної тканини (8,92%), системи кровообігу $(5,91 \%)$, нервової системи $(3,46 \%)$, ока та його придаткового апарату $(2,00 \%)$. Слід відмітити, що вік людини відіграє важливу роль у появі багатьох захворювань. Хоча деякі захворювання виникають у молодому віці, проте більш негативні наслідки перенесених захворювань спостерігаються саме з віком, особливо після сорока років.

Профресійна діяльність працівників атомних станцій потребує підвищеної уваги, готовності до екстрених ситуацій, загальної стійкості організму до несприятливих дій зовнішнього та виробничого середовища. Висуває підвищенні вимоги до зорового аналізатора [8-10].

Найбільш важливими психофрізіологічними властивостями для успішної професійної діяльності $\epsilon$ обсяг уваги, концентрація уваги, пам'ять, врівноваженість, логічне мислення, розподіл і переключення уваги, оперативне мислення та емоційна стійкість.

Аналіз фрахової літератури та експертна оцінка дали змогу визначити характерну робочу позу, рухову активність, профресійно важливі рухові уміння і навички; фрізичні і психофрізіологічні якості та властивості; важливі якості особистості, необхідні для ефективної праці. У бесідах з персоналом Рівненської АЕС встановлено, що більшість працівників протягом робочого дня відчувають легке стомлення. Як стверджують фахівці, втома відчувається в різні періоди робочої зміни. Вже на початку робочого дня, впродовж першої години ії відчувають $2,1 \%$ опитаних, через $2-3$ год. $-4,2 \%$, після 4-5 год. - 13,5\%, через 5-6 год. - 17,7 \% працівників. Наприкінці робочого дня більше половини працівників $(59,4$ \%) відчувають значну втому. Не однаково проявляється і характер втоми. Так, 9,4 \% фахівців відзначають, що відчувають біль в очах, у $11,5 \%$ опитаних знижується настрій, а у 16,2 \% - координація рухів. Апатію як прояв втоми відчувають $18,8 \%$ респондентів, біль у суглобах - 19,8 \%, відчуття роздратованості - 22,9 \%, зниження уваги і головний біль - 28,1 і 32,3 \% відповідно. Такі ознаки втоми, як слабкість, помітили 34,4 \% працівників, небажання спілкуватися - 35,4 \%, зниження концентрації уваги - 38,5 \%. Значний відсоток опитаних вказали на такі симптоми втомлюваності, як біль у спині та шиї - 44,8 \%, сонливість $-53,1 \%$. Таким чином, симптоматика втомлюваності $\epsilon$ дуже індивідуальною і залежить від функціонального стану організму працівника та ступеня відповідальності за роботу. Але резерви людини не нескінченні, і якщо нехтувати повноцінним відпочинком та засобами відновлення, то це може призвести до травмування i нещасних випадків на виробництві.

Багато фахівців пояснюють втому досить важкими умовами праці, значним нервово-емоційним напруженням, працею у стресових або надзвичайних ситуаціях, великою відповідальністю за безпеку роботи та життя людей, працею у шкідливих умовах [1].

Особливості діяльності персоналу АЕC обумовлені специфікою праці. Головною умовою продуктивної праці $\epsilon$ вміння швидко орієнтуватися в складних умовах виробництва та впродовж робочого дня підтримувати високий рівень працездатності. Добре фрізично підготовлена людина легше переносить неспецифрічну адаптацію, легше сприймає дію шкідливих умов праці, стійкіша до інфрекцій та різних захворювань.

Висновки та перспективи подальших досліджень. Системний аналіз наукової літератури 3 проблеми дослідження дозволив встановити, що питанням розробки реабілітаційних, профрілактично-оздоровчих та рекреаційних програм на виробництві присвячено достатню кількість вітчизняних та зарубіжних досліджень, в яких наголошується про доцільність, важливість, актуальність та необхідність проведення зазаначених заходів на робочому місці. Водночас високі вимоги, що висуваються до працівників галузі атомної енергетики, свідчать про ряд основних протиріч між стрімким розвитком галузі й потребою у висококваліфікованих фрахівцях, здатних до тривалого професійного довголіття, та недостатньою розробленістю змісту наявних програм 3 фрізичної реабілітації та рекреації в концептуальному розумінні; між високими вимогами, що висуваються до фрізичної підготовленості сучасних фахівців галузі атомної енергетики та наявним рівнем показників фрізичного та психоемоційного станів працівників. Недостаній рівень рухової активності, фрізичного та психоемоційного станів, захворюваність працівників ВП РАЕС зумовлює актуальність наукового обгрунтування вдосконалення змісту, розробки та впровадження чіткої системи реабілітаційних, оздоровчих, професійно-прикладних фрізкультурних заходів, спрямованих на збереження та підвищення здатності людини до трудової діяльності на виробництві.

Під час здійснення предметного аналізу специфічних особливостей професійної діяльності фрахівців було використано наукові дослідження вітчизняних і закордонних авторів. На основі 
принципів системного підходу і всебічного ретельного вивчення професійної діяльності фахівців атомної галузі, програмно-нормативних джерел, професіограсрічних досліджень, даних анкетування фрахівців, освітньо-кваліфікаційних характеристик, довідників професій, наявних захворювань, скарг працівників було складено експерименталь-

\section{Література}

1. Андрєєва О. Теоретико-методологічні засади рекреаційно діяльності різних груп населення / О. Андрєєва // Теорія і методика фіз. виховання і спорту. - 2015. - № 2. - С. 16-28.

2. Андрєєва О. Розробка та впровадження технології проектування активної рекреаційної діяльності різних груп населення / О. Андрєєва // Спорт. вісн. Придніпров'я. - 2015. - № 1. - С. 4-9.

3. Благий А. Формирование профессиональных компетенций фитнес-тренера для работы с корпоративными клиентами / А. Благий, Н. Лисакова // Материалы междунар. науч. конф. Проблемы акмеологии в области физической культуры. - Кишинев: ГУФВС. - 2018. - С. 100104.

4. Благій О. Л. Сучасні підходи до управління фізичним станом чоловіків зрілого віку в процесі кондиційного тренування / О. Л. Благій // Теорія і методика фіз. виховання і спорту. - 2015. - № 1. - С. $22-25$.

5. Благій О. Л. Аналіз підходів щодо профрілактики офісного синдрому засобами оздоровчо-рекреаційної рухової активності / О. Л. Благій, В. О. Благій // Фізична культура і спорт: досвід та перспективи: матеріали II Міжнар. наук.-практ. конф. - Чернівці, 2019. - С. 54-55.

6. Дутчак М. В. Парадигма оздоровчої рухової активності: теоретичне обґрунтування і практичне застосування / М. В. Дутчак // Теорія і методика фріз. виховання і спорту. - 2015. - № 2. - С. 44-52.

7. Лазарєва О. Б. Динаміка якості життя хворих з ожирінням під впливом програми фізичної реабілітації / О. Б. Лазарєва, М. Г. Аравіцька // Спорт. медицина та фіз. реабілітація. - 2017. - № 1. - С. 72-78.

8. Огнистий А. В. Основи професійно-прикладної фрізичної підготовки: навч. посіб. - Тернопіль: ТНПУ, 2007. - 104 с.

9. Раєвський Р. Т. Профресійно-прикладна фізична підготовка студентів вищих навчальних закладів: навч.-метод. посіб. / А. В. Огнистий, К. М. Огниста, О. І. Кривокульський, М. В. Божик // Одеса: Наука і техніка, 2010. -380 c

10. Халайджі С. В. Соціальне замовлення на професійно-прикладну психофрізіологічну і психофрізичну підготовку фахівців енергетичного комплексу / С. В. Халайджі // Молода спортивна наука України: зб. наук. пр. в галузі фіз. культури та спорту. - Т. 3, вип. 9. - Львів: Укр. технології, 2005. - C. 129

11. Active Communities Workplace: workbook. - Burnaby: British Columbia Recreation and Parks Association, 2006. - 81 p. ні програми фрізичної реабілітації, профрілактичнооздоровчих та рекреаційних занять.

Перспективи подальших досліджень полягають в оцінці ефективності розроблених профрілактично-оздоровчих, рекреаційних та реабілітаційних заходів для працівників атомних електростанцій.

\section{Reference}

1. Андрєєва О. Теоретико-методологічні засади рекреаційної діяльності різних груп населення [Theoretical and methodological principles of recreational activities of different population groups]. Теорія і методика фізичного виховання і спорту. 2015;(2):16-28.

2. Андрєєва О. Розробка та впровадження технології проектування активної рекреаційної діяльності різних груп населення [Development and implementation of technology for the design of active recreational activities of various population groups]. Спортивний вісник Придніпров'я. 2015;(1):4-9.

3. Благий А, Лисакова Н. Формирование профессиональных компетенций фитнес-тренера для работы с корпоративными клиентами [Formation of professional competences of a fitness coach for working with corporate clients]. B: Материалы междунар. науч. конф. «Проблемы акмеологии в области физической культуры». Кишинев: ГУФВС; 2018. c. $100-4$

4. Благій ОЛ. Сучасні підходи до управління фізичним станом чоловіків зрілого віку в процесі кондиційного тренування [Modern approaches to the management of the physical condition of men of mature age in the process of conditioning training]. Теорія і методика фізичного виховання і спорту. 2015;(1):22-5.

5. Благій ОЛ, Благій ВО. Аналіз підходів щодо профілактики офісного синдрому засобами оздоровчо-рекреаційної рухової активності [Analysis of approaches to prevention of office syndrome by means of health related and recreational motor activity]. В: «Фізична культура і спорт: досвід та перспективи»: матеріали II Міжнар. наук.-практ. конф. Чернівці; 2019. с. 54-5.

6. Дутчак МВ. Парадигма оздоровчої рухової активності: теоретичне обґрунтування і практичне застосування [Paradigm of recreational motor activity: theoretical substantiation and practical application]. Теорія $\boldsymbol{i}$ методика фізичного виховання і спорту. 2015;(2):44-52.

7. Лазарєва ОБ, Аравіцька МГ. Динаміка якості життя хворих з ожирінням під впливом програми фізичної реабілітації [Dynamics of quality of life of obese patients under the influence of the program of physical rehabilitation]. Спортивна медицина та фізична реабілітація. 2017;(1):72-8.

8. Огнистий АВ, Огниста КМ, Кривокульський ОІ, Божик МВ. Основи професійно-прикладної фізичної підготовки [Basics of professional-applied physical training]. Тернопіль: ТНПУ; 2007. 104 с.

9. Раєвський РТ, Канішевський СМ. Професійно-прикладна фізична підготовка студентів вищих навчальних закладів [Professional-applied physical training of students at higher educational institutions]. Одеса: Наука і техніка, 2010. 380 c.

10. Халайджі СВ. Соціальне замовлення на професійно-прикладну психофізіологічну і психофізичну підготовку фахівців енергетичного комплексу [Social order for professional-applied psychophysiological and psychophysical training of specialists in the energy complex] . В: Молода спортивна наука України: зб. наук. пр. в галузі фіз. культури та спорту. Вип. 9, т. 3. Львів: Українські технології; 2005. с. 129.

11. Active Communities Workplace: workbook. Burnaby: British Columbia Recreation and Parks Association; 2006. 81 p. 